\title{
URGENSI PENGATURAN PERUSAHAAN GADAI SWASTA DENGAN SISTEM ONLINE
}

\author{
Annisa Hanifah, Budi Santoso dan Ismail Navianto \\ Program Studi Magister Kenotariatan Pasca Sarjana Fakultas Hukum \\ Universitas Brawijaya \\ email: annisahanifah10@gmail.com, busan04@gmail.com dan isnavianto@gmail.com
}

\begin{abstract}
Nowadays Pawn Company has used business services activities with the system through media electronic (online). POJK Usaha Pergadaian is not enough to set the regulation. There is not a single phrase in the regulation about peculiarities of Pawn Company with online system. The regulations are required because the pawn process in online pawn is different on a general pawn, as an example of the assessments that must be performed by a certified estimator conducted at a pawnshop outlet, and it related to the delivery of goods, and what if the goods delivered are not items that have been assessed by the online estimator and related to the issues that concerning about the regulation of partnership license of the pawn company, whether including outlet or not. And Internet coverage that borderless becomes that matter itself. Even though, POJK Usaha Pergadaian regulate about the pawn company performs its activities in accordance with the territorial permits granted by OJK. Furthermore, the uncompletetly law condition caused by the absence of this online legal pawn regulation will caused to legal uncertainty.
\end{abstract}

Keywords: Pawn Company, Online System and Legal Certainty.

\begin{abstract}
Abstrak
Perkembangannya perusahaan gadai swasta ini telah ada yang menggunakan layanan kegiatan usaha dengan sistem melalui media elektronik (online). POJK Usaha Pergadaian nyatanya tidak cukup dalam mengatur. Tidak ada satu frasapun di dalam peraturan itu yang mengatur kekhasan perusahaan gadai online. Pengaturan dibutuhkan karena proses gadai dalam gadai online berbeda pada gadai umumnya. Sebagai contoh terkait penaksiran yang mana wajib dilakukan oleh penaksir bersertifikat dilakukan di outlet perusahaan gadai, terkait penyerahan barang, bagamaina jika barang yang dikirim bukanlah barang yang telah ditaksir oleh penaksir secara online dan terkait permasalahan pengaturan izin kemitraan perusahaan gadai, apakah termasuk outlet atau bukan. Jangkauan internet yang menembus batas wilayah kota bahkan provinsi hingga batas negara menjadi problem tersendiri, padahal POJK Usaha Pergadaian mengatur bahwa perusahaan gadai melakukan kegiatannya sesuai dengan izin wilayah yang diberikan oleh OJK. Lebih lanjut kondisi uncompletetly law yang disebabkan oleh tidak adanya pengaturan (kekosongan hukum) gadai secara online ini pada gilirannya akan menimbulkan ketidakpastian hukum.
\end{abstract}

Kata Kunci: Perusahaan Gadai, Sistem Online dan Kepastian Hukum. 


\section{PENDAHULUAN}

Perkembangan ekonomi dewasa ini semakin pesat khususnya dalam hal pemenuhan kebutuhan hidup masyarakat akan modal. Sebagai contoh untuk membuka suatu lapangan usaha tidak hanya diperlukan bakat atau keahlian tetapi juga memerlukan modal. Keberadaan lembaga yang menyediakan modal (pinjaman) menjadi sangat penting bagi masyarakat.

Perusahaan gadai merupakan salah satu lembaga yang menyediakan pinjaman yang dimaksud. Perusahaan gadai menawarkan kemudaahan mendapatkan pinjaman sehingga menjadi solusi alternatif bagi masyarakat ditengah sulitnya mendapatkan pinjaman dari lembaga penyedia pinjaman seperti bank. ${ }^{1}$ Gadai pada prakteknya diminati oleh masyarakat. ${ }^{2}$

Umumnya perusahaan gadai merupakan Badan Usaha Milik Negara (BUMN) yakni PT. Pegadaian (Persero). ${ }^{3}$ Namun demikian telah terdapat banyak perusahaan gadai swasta yang melakukan kegiatan usahanya di Indonesia. OJK menyebutkan terdapat sekitar 4000-hingga

\footnotetext{
${ }^{1}$ https://www.merdeka.com/uang/untungmana-pinjam-dari-bank-pegadaian-atau-rentenironline.html. Diakses pada tanggal 22 Januari 2018.

${ }^{2}$ Gadai ialah hak yang diperoleh seorang yang mempunyai piutang atas suatu benda bergerak, yang diserahkan kepadanya oleh seseorang berutang atau seseorang lain atas namanya dan yang memberikan kekuasaan kepada si berpiutang untuk mengambil pelunasan dari benda tersebut secara didahulukan dari pada orang lain yang berpiutang dengan dikecualian biaya untuk melelang benda dan biaya yang telah dipergunakan untuk menyelamatkan segala benda yang digadaikan, dan mana biaya-biaya yang harus didahulukan. Lihat Subekti, KUHPerdata (Jakarta: Pradnya Paramita, 2001), 297.

${ }^{3}$ PT. Pegadaian (Persero) merupakan satusatunya perusahaan gadai berizin di Indonesia. Hingga terbitnya POJK Usaha Pergadaian, seluruh perusahaan gadai swasta yang menjalankan usahanya di Indonesia tidak memiliki dasar hukum yang jelas. Dasar hukum Pegadaian adalah PP No. 103 Tahun 2000 tentang Perusahaan Umum Pegadaian yang telah diperbaharui PP No. 51 Tahun 2011 tentang Perubahan Bentuk Badan Hukum Perusahaan Umum Pegadaian Menjadi Perusahaan Persero.
}

5000 gadai swasta yang beroperasi di Indonesia. ${ }^{4}$

Eksistensi perusahaan gadai swasta ini ternyata ditangkap oleh pemerintah sebagai suatu potensi kekuatan finansial yang sangat baik bagi masyarakat. Pada tahun 2016 pemerintah telah menerbitkan aturan yang menjadi dasar keberadaan perusahaan gadai swasta yakni "Peraturan Otoritas Jasa Keuangan Nomor 31/POJK. 05 Tahun 2016 tentang Usaha Pergadaian" (selanjutanya disebut "POJK Usaha Pergadaian").

Terbitnya POJK Usaha Pergadaian merupakan trobosan yang sangat maju karena sejak pemerintahan kolonial belanda hingga tahun 2016 lalu pegadaian (perusahaan gadai) merupakan monopoli perusahaan gadai negara. Diharapkan perusahaan gadai swasta segera mendaftarkan dirinya di OJK, sehingga jelas legalitas perusahaan gadai swasta tersebut. ${ }^{5}$

Secara berkelanjutan keberadaan perusahaan gadai swasta ini pada perkembangannya telah ada yang menggunakan layanan kegiatan usaha dengan sistem melalui media elektronik (online). Perkembangan gadai dengan sistem online ini seiring dengan kemajuan teknologi dan sistem informasi di bidang financial technology (FinTech). Situs-situs seperti gadaionline.com, pinjam.co.id, gadai247.com, dan gadaibarang.com telah hadir sebagai bentuk gadai di dunia maya. Namun demikian kemajuan perkembangan sektor gadai yang pesat ini tidak diikuti dengan pengaturan yang memadai.

POJK Usaha Pergadaian yang sementara ini menjadi "gantungan" legal standing perusahaan gadai dengan sistem online nyatanya tidak cukup dalam mengatur. Tidak ada satu frasapun di dalam

${ }^{4}$ OJK Terbitkan Izin Gadai Swasta pada Januari 2016, http://financial.id/newsreader/2089. Diakses pada tanggal 22 Januari 2018.

${ }^{5}$ Pasal 5 Ayat (3) POJK Usaha Pergadaian: "permohonan pendaftaran sebagaimana dimaksud pada ayat (1) diajukan kepada OJK paling lama 2 (dua) tahun sejak Peraturan OJK ini diundangkan”. 
peraturan itu yang mengatur kekhasan perusahaan gadai online, padahal dalam Penjelasan Pasal 13 Ayat (1) POJK Usaha Pergadaian disebutkan bahwa:

"Layanan kegiatan Usaha Pergadaian dalam ketentuan ini dapat dilakukan melalui media elektronik", 6

Penjelasan pasal tersebut merupakan suatu kebolehan bagi perusahaan gadai untuk melakuan kegiatan usahanya secara online.

Pengaturan yang lebih spesifik (lex specialis) menjadi sangat penting karena proses gadai dalam gadai online berbeda dengan gadai pada umumnya. Sebagai contoh dalam hal penaksiran yang mana wajib dilakukan oleh penaksir bersertifikat dilakukan di outlet perusahaan gadai, dalam gadai online hal ini masih menimbulkan pertanyaan. $^{7}$

Permasalahan berikutnya adalah terkait penyerahan barang, bagamaina jika barang yang dikirim bukanlah barang yang telah ditaksir oleh penaksir secara online dan terkait permasalahan pengaturan kemitraan perusahaan gadai, apakah termasuk outlet atau bukan. Jangkauan internet yang menembus batas wilayah kota bahkan provinsi hingga batas negara menjadi problem tersendiri, padahal POJK Usaha Pergadaian mengatur bahwa perusahaan gadai melakukan kegiatannya sesuai dengan izin wilayah yang diberikan oleh OJK.

Lebih lanjut kondisi uncompletetly law ${ }^{8}$ yang disebabkan oleh tidak adanya pengaturan (kekosongan hukum) gadai

\footnotetext{
${ }^{6}$ Penjelasan Pasal 13 Ayat (1) POJK Usaha Pergadaian.

${ }^{7}$ Pasal 19 Ayat (1) POJK Usaha Pergadaian: "Wajib memiliki paling sedikit 1 (satu) orang Penaksir untuk melakukan penaksiran atas Barang Jaminan pada setiap unit pelayanan (outlet)".

${ }^{8}$ Penjelasan mengenai uncompletetly law atau uncomplete of norm atau dalam bahasa Indonesia dikenal dengan istilah hukum yang tidak komplit, yaitu hukum yang mengatur sesuatu yang ada, tetapi tidak lengkap. Dikutip dari Isrok, Masalah Hukum Jangan Dianggap Sepele Menyoal The Devils Is In The Detail Sebagai Konsep Teori (Malang: Fakultas Hukum Universitas Brawijaya, 2017), 242.
}

secara online ini pada gilirannya akan menimbulkan ketidakpastian hukum. Kondisi ketidakpastian hukum tentunya tidak baik bagi perkembangan ekonomi di Indonesia. Dengan kondisi pengaturan yang demikian itu maka penting untuk mengetahui urgensi pengaturan perusahaan gadai khususnya perusahaan gadai swasta secara online secara lebih mendalam. Setelah mengetahui urgensi pengaturan gadai secara online maka dapat diketahui bagaimana pengaturan yang dibutuhkan perusahaan gadai swasta dengan sistem online tersebut.

Berdasarkan latar belakang yang telah dikemukakan diatas, rumusan permasalahan dalam penulisan jurnal yaitu bagaimana urgensitas pengaturan perusahaan gadai swasta dengan sistem online? Dan apa saja pengaturan yang dibutuhkan perusahaan gadai swasta dengan sistem online?

\section{LITERATURE REVIEW}

Penelitian tentang urgensi pengaturan perusahaan gadai swasta dengan sistem online bukanlah hal yang baru. Berikut beberapa karya yang terdokumentasikan terkait permasalahan yang dikaji, yaitu pertama, Salim, dalam "Perkembangan Hukum Jaminan di Indonesia" menyatakan bahwa keunggulan gadai daripada lembaga penyedia pinjaman lainnya adalah kecepatan perusahaan gadai dalam "mencairkan" pinjaman, debitor cukup menyerahkan barang jaminan kepada juru taksir, maka dalam waktu yang singkat debitor akan menerima pinjaman. ${ }^{9}$

Kedua, Hermansyah dalam "Hukum Perbankan Nasional Indonesia". 10 Menurut Hermansyah, landasan yuridis pembentukan Undang-Undang OJK dilandasai oleh Undang-Undang Nomor 3 Tahun 2004

\footnotetext{
${ }^{9}$ Salim, Perkembangan Hukum Jaminan di Indonesia (Jakarta: Rajawali Pers, 2016), 39.

${ }^{10}$ Hermansyah, Hukum Perbankan Nasional Indonesia (Jakarta: Kencana Prenadamedia Group, 2005), 219.
} 
tentang Bank Indonesia (selanjutnya disebut UU BI). Hal ini secara tegas diatur didalam Pasal 34 UU BI, yang mengamanatkan pembentukan lembaga pengawas sektor jasa keuangan yang mencakup perbankan, asuransi, dana pension, sekuritas, modal ventura dan perusahaan pembiayaan serta badan-badan lain yang menyelenggarakan pengelolaan dana masyarakat. Lembaga pengawasan sektor jasa keuangan ini disebut Otoritas Jasa Keuangan (OJK).

Dari kedua penelitian terdahulu yang telah dipaparkan di atas, ternyata belum ada tinjauan secara khusus dan komprehensif tentang urgensi pengaturan perusahaan gadai swasta dengan sistem online ditinjau dari hukum positif dan hukum ekonomi syariah. Dengan menggunakan tinjauan hukum positif dan hukum ekonomi syariah pada penelitian ini diharapkan akan mengungkapkan perusahaan gadai swasta dengan sistem online. Di sinilah letak perbedaan studi ini dengan studi-studi yang telah dilakukan sebelumnya.

\section{METODOLOGI PENELITIAN}

Metode penelitian yang digunakan dalam penulisan jurnal ini adalah penelitian yuridis normatif yakni mengkaji mendalam mengenai urgensi pengaturan perusahaan gadai swasta dengan sistem online. Selanjutnya dalam penulisan jurnal ini menggunakan pendekatan perundangundangan (statute approach), yakni yang mengkaji, menelaah dan menganalisis peraturan yang berkaitan dengan pengaturan perusahaan gadai swasta dengan sistem online dan pendekatan konseptual (conceptual approach), yakni pendekatan melalui konsep-konsep yang dapat ditemukan dalam pendapat-pendapat sarjana yang memiliki relevansi dengan permasalahan pengaturan perusahaan gadai swasta dengan sistem online.

Selain itu, penulis menggunakan metode penelitian kualitatif, yang berusaha menggali, memahami, dan mencari fenomena sosial. Fenomena sosial yang dimaksud adalah permasalahan pengaturan perusahaan gadai swasta dengan sistem online. Dengan menggunakan metode kualitatif ini dapat menghasilkan data deskriptif berupa kata-kata tertulis atau lisan dari narasumber. Pengumpulan data dilakukan dengan cara observasi dan wawancara secara terbuka.

Dalam penelitian kualitatif ini digunakan teknik pengumpulan data yang meliputi observasi, wawancara mendalam serta kajian literatur. Observasi merupakan pengumpulan data dengan cara mengamati secara langsung objek yang diteliti dilokasi penelitian. Dari penelitian observasi kita dapat melihat secara langsung pola perilaku pengaturan perusahaan gadai swasta dengan sistem online, sehingga dengan obeservasi ini peneliti dapat menjaring informasi atau data. Tidak hanya itu, dalam penelitian inipun menggunakan pendekatan normatif yang dilakukan dengan cara meneliti bahan pustaka yang ada.

\section{KONSEP DASAR}

\section{Urgensi Pengaturan Perusahaan Gadai Swasta dengan Sistem Online}

Urgensi pengaturan perusahaan gadai swasta dengan sistem online terdapat disharmonisasi pengaturan gadai milik negara, gadai swasta offline dan gadai swasta dengan sistem online. Selain itu tidak adanya pengaturan terkait penyerahan barang, terkait penaksir, terkait dengan lingkup wilayah usaha, terkait kemitraan, terkait izin dan terkait dengan barang apa yang dapat digadaikan menyebabkan kekosongan hukum gadai swasta dengan sistem online.

Kekosongan hukum juga dapat diartikan sebagai suatu keadaan kosong atau ketiadaan peraturan perundang-undangan (hukum) yang mengatur tata tertib (tertentu) dalam masyarakat, apabila kekosongan hukum ditinjau dalam Hukum Positif lebih tepat dikatakan sebagai kekosongan undangundang atau peraturan perundang-undangan.

Lebih jauh akibat yang ditimbulkan dengan adanya kekosongan hukum, terhadap hal-hal atau keadaan yang tidak 
atau belum diatur itu dapat terjadi ketidakpastian hukum karena belum diatur secara spesifik sehingga dalam proses gadai antara satu perusahaan gadai swasta dengan sistem online yang satu dan yang lainnya berbeda cara menjalankan usahanya dan kerugian ${ }^{11}$ bagi individu yang dirugikan hak dan kewajiban, kemudian selanjutnya kerugian lainnya yang akan nampak dari adanya kekosongan hukum suatu pengaturan mengenai gadai swasta online adalah perkembangan ekonomi dalam rangka untuk meningkatkan inklusi keuangan ${ }^{12}$ bagi masyarakat mikro, makro dan usaha kecil dan menengah.

\footnotetext{
${ }^{11}$ Kerugian yang dimaksud penulis adalah yang dikemudian hari dimungkinkan akan menimbulkan suatu kerugian, apabila tidak diatur. Hal ini selaras dengan ius constituendum yaitu hukum yang dicita-citakan (masa mendatang), kemudian Sudikno Mertokusumo dalam bukunya yang berjudul Penemuan Hukum Sebuah Pengantar mengemukakan bahwa ius constituendum hukum yang masih harus ditetapkan; hukum yang akan datang. Dikutip dari Sudikno Mertokusumo, Penemuan Hukum Sebuah Pengantar (Yogyakarta: Liberty, 2006), 120. Menurut Soerjono Soekanto dan Punardi Purbacaraka dijelaskan bahwa ius constituendum adalah hukum yang dicita-citakan dalam pergaulan hidup negara, tetapi belum dibentuk menjadi undang-undang atau ketentuan. Di kutip dari Soerjono Soekanto dan Punardi Purbacaraka, Aneka Cara Pembedaan Hukum (Bandung: PT. Citra Aditya Bakti, 1994), 5.

${ }^{12}$ Inklusi keuangan adalah salah satu program kerja Presiden Joko Widodo, yang mempunyai arti memudahkan akses masyarakat terhadap layanan atau jasa keuangan. Sebab Pemerintah RI menargetkan tingkat inklusi keuangan pada tahun 2019 Negara Indonesia sudah bisa menyamai negara-negara lain yang selama ini sudah maju diantaranya India. Presiden Joko Widodo menginginkan seluruh masyarkat Indonesia dapat megakses lembaga keuangan secara sederhana dan cepat. "kita ingin semua orang itu bisa mengakses perbankan dan akses sektor keuangan yang ada secara sederhana dan cepat. Semuanya, seluruh masyarakat bisa masuk ke sistem keuangan," katanya. Dalam http://finansial.bisnis.com/read/20180213/9/738201/j okowi-beberkan-penghambat-perluasan-inklusikeuangan-indonesia. Diakses pada tanggal 13 Februari 2018.
}

Seharusnya hukum itu harus dapat menciptakan kepastian hukum. Lebih lanjut Abdul Rachmad Budiono mengemukakan bahwa indikator adanya kepastian hukum suatu negara itu sendiri adalah dengan adanya suatu peraturan perundang-undangan yang jelas dan perundang-undangan tersebut diterapkan dengan baik oleh hakim maupun petugas hukum lainnya. ${ }^{13}$

Selanjutnya menurut Muhammad Ali Safa'at yang di dalam bukunya berjudul Antonasi Pemikiran Hukum mengemukakan bahwa kepastian tidak bisa dipisahkan dari hukum terutama dalam hukum positif atau peraturan perundang-undangan. ${ }^{14}$ Hukum tanpa adanya nilai kepastian akan kehilangan makna karena tidak dapat lagi digunakan sebagai pedoman perilaku bagi setiap orang. Pada dasarnya kepastian mengandung unsur kejelasan, tidak mengakibatkan adanya multitafsir, maupun kontradiksi sehingga tidak menjadi sumber keraguan. Hukum harus jelas maksudnya kepada masyarakat bahkan hukum juga harus mengandung keterbukaan sehingga dengan siapa dapat dipahami makna atas suatu ketentuan hukum. ${ }^{15}$

\section{PEMBAHASAN DAN DISKUSI: Harmonisasi Pengaturan Gadai}

Pengaturan gadai memiliki 2 (dua) rezim pengaturan. Pertama, pengaturan perusahaan gadai milik Negara/ PT. Pegadaian (Persero) diatur melalui PP. Kedua, pengaturan perusahaan gadai milik swasta yang diatur melalui POJK. Perbedaan pengaturan tersebut menyebabkan terjadinya perbedaan strata pengaturan untuk materi muatan yang sama yakni mengenai perusahaan gadai. Sehingga perbedaan pengaturan untuk materi muatan yang sama akan menimbulkan konsekuensi hukum yang berbeda.

\footnotetext{
${ }^{13}$ Abdul Rachmad Budiono, Pengantar Ilmu Hukum (Malang: Bayumedia Publishing, 2005), 22.

${ }^{14}$ Muhammad Ali Safaat, Antonasi Pemikiran Hukum (Malang: UB Press, 2014), 103.

${ }^{15}$ Muhammad Ali Safaat, Antonasi Pemikiran Hukum, 103.
} 
Perbedaan strata pengaturan tersebut terletak pengaturan untuk PT. Pegadaian berdasarkan PP dan PP termasuk dalam hierarki peraturan perundang-undangan yang terdapat dalam pasal 7 ayat (1) UU No. 12 Tahun 2011 tentang Pembentukan Peraturan Perundang-undangan (selanjutnya disebut UU Pembentukan Perundangundangan). ${ }^{16}$ Sedangkan untuk pengaturan perusahaan gadai swasta diatur melalui lembaga yang dibuat atau diamanatkan melalui undang-undang. Lembaga yang dimaksud adalah Otoritas Jasa Keuangan ${ }^{17}$

\footnotetext{
${ }^{16}$ Pasal 7 ayat (1) UU No. 12 Tahun 2011 tentang Pembentukan Peraturan Perundangundangan, yang berbunyi: "Jenis dan hierarki peraturan perundang-undangan terdiri atas:

a. Udang-Undang Dasar Negara Republik Indonesia Tahun 1945;

b. Ketetapan Majelis Permusyawaratan Rakyat;

c. Undang-Undang/Peraturan Pemerintah Pengganti Undang-Undang;

d. Peraturan Pemerintah;

e. Peraturan Presiden;

f. Peraturan Daerah Provinsi; dan

g. Peraturan Daerah Kabupaten/Kota.

${ }^{17}$ Selain alasan amanat pasal 34 UU BI
} alasan lain yang mendasari dibentuknya lembaga OJK, dikemukakan oleh Hamud M. Belfas bahwa alasan didirikannya OJK disebabkan pengawasan atas industri jasa keuangan dengan struktur seperti sekarang dianggap sudah tidak memadai.

17 Dengan adanya OJK, pengawasan atas semua industri jasa keuangan akan disatukan ke dalam satu atap, yaitu perbankan, pasar modal, asuransi, dana pensiun, lembaga keuangan non-bank. Secara yuridis, menurut ketentuan pasal 1 angka (1) UU OJK, dirumuskan bahwa, “...OJK adalah lembaga yang independen dan bebas dari campur tangan pihak lain, yang mempunyai fungsi, tugas dan wewenang pengaturan, pengawasan, pemeriksaan dana penyidikan sebagaimana dimaksud dalam undang-undang ini". Berdasarkan penjelasan mengenai lembaga OJK, disebutkan bahwasanya OJK mempunyai wewenang membuat pengaturan yang berhubungan dengan perbankan, pasar modal, asuransi, dana pensiun, lembaga pembiayaan dan lembaga jasa keuangan lainnya. Dalam UU OJK disebutkan bahwa yang pergadaian termasuk lembaga jasa keuangan lainnya. Hal inilah yang menjadi dasar diaturnya perusahaan gadai swasta berdasarkan POJK Usaha Pergadaian. Lihat UndangUndang Nomor 21 Tahun 2011 tentang Otoritas Jasa Keuangan. yang disahkan berdasarkan Undang-Undang Nomor 21 Tahun 2011 tentang Otoritas Jasa Keuangan (selanjutnya disebut UU OJK). ${ }^{18}$

Perbedaan pengaturan tersebut pada akhirnya menimbulkan kerancuan karena POJK $^{19}$ tidak masuk dalam tata urutan hierarki peraturan perundang-undangan. Namun keberadaanya tetap diakui dan mempunyai kekutaan hukum mengikat sepanjang diperintahkan oleh peraturan perundang-undangan yang lebih tinggi atau dibentuk berdasarkan kewenangan. ${ }^{20}$

Kerancuan yang dimaksud adalah seputar pengaturan mengenai pegadaian baik itu pegadaian milik negara maupun pegadaian swasta tersebar dalam berbagai macam pengaturan yang menyakibatkan tumpang tindih pengaturan. Sebagai contoh apakah dalam melakukan usaha gadai swasta juga tunduk terhadap PP No. 51 Tahun 2011 mengenai pegadaian milik Negara yakni PT. Pegadaian (Persero) $?^{21}$

${ }^{18}$ Lihat Pasal 2 Ayat (1) Undang-Undang Nomor 21 Tahun 2011 tentang Otoritas Jasa Keuangan, yang berbunyi “...dengan undang-undang ini dibentuk OJK".

${ }^{19}$ POJK adalah sebuah peraturan tertulis yang ditetapkan oleh dewan komisoner, mengikat secara umum dan diundangkan dalam lembaran Negara Republik Indonesia. Lihat ketentuan Pasal 1 Angka (11) UU OJK.

${ }^{20}$ Lihat Pasal 8 Ayat (2) UU Pembentukan Perundang-undangan. Dalam ketentuan Pasal 8 Ayat (1) dikatakan bahwasanya “...Jenis peraturan perundang-undangan selain sebagaimana dimaksud dalam Pasal 7 Ayat (1) mencakup peraturan yang ditetapkan oleh MPR, DPR, MA, MK, BPK, KY, BI, Menteri, badan, lembaga atau komisi yang setingkat yang dibentuk dengan UU atau Pemerintah atas perintah UU, DPRD Provinsi, Gubernur, DPRD Kab/Kota, Bupati/Walikota, Kepala Desa atau yang setingkat.

${ }^{21}$ Sebab di dalam ketentuan PP No. 103 Tahun 2000 tentang Perum Pegadaian, ditegaskan bahwa Pegadaian adalah satu-satunya badan usaha yang menyelenggarakan kegiatan pergadaian. Kemudian lebih lanjut apabila melihat ketentuan di konsideran POJK Usaha Pergadaian dasar mengingatnya hanya terdapat UU OJK. Dan di dalam ketentuan PP No. 51 Tahun 2011, tidak ada klausula yang menyebutkan PP No. 103 Tahun 2003 tidak berlaku. Sehingga dapat dikatakan PP No. 103 Tahun 
Menurut hemat penulis perlu adanya undang-undang sebagai acuan dasar atau umum $^{22}$ yang mengatur mengenai perusahaan gadai. Sehingga pengaturan gadai yang tersebar dalam berbagai pengaturan diakhiri dengan adanya suatu dasar hukum yang kuat yang menjadi dasar segala peraturan di bawahnya, agar seluruh peraturan mengenai perusahaan gadai runtut atau urut dari peraturan yang di atas sampai yang di bawahnya.

Hal itu berksesuaian dengan stufentheorie yang diperkenalkan oleh Hans Kelsen yang mengemukakan bahwasanya tata urutan hierarki peraturan perundangundangan itu dirumuskan secara berjenjang, dan berlapis-lapis, di mana peraturan perundang-undangan yang lebih rendah selalu bersumber dan berdasar pada peraturan perundang-undangan yang lebih tinggi. $^{23}$

Dalam hal ini Muchtar
Kusumaatmadja mengatakan bahwa,
hierarki peraturan perundang-undangan
didasarkan pada asas lex superiori derogat

2000 masih berlaku sepanjang dinyatakan sudah tidak berlaku atau dicabut.

${ }^{22}$ UU yang berisi norma-norma hukum yang beralaku umum. Ketentuan bahwa UU "berlaku umum", menurut F.R Bohthngk mengandung berbagai konsekuensi, yakni:

a. "umum" itu dapat berhubungan dengan ruang lingkup berlakunya, dalam arti berlaku dimanamana;

b. "umum" itu dapat berhubungan dengan lingkup waktu, dalam arti berlaku terus menerus tanpa maksud terlebih dahulu akan mengubah atau menariknya;

c. "umum" itu dapat berhubungan dengan subjek hukum yang terkena norma tersebut, yakni tidak boleh bersifat individual karena kebenaran, demikian juga UU, berlaku untuk semua orang;

d. "umum" itu akhirnya berhubungan dengan fakta hukum dan hukum tersebut harus merupakan fakta yang selalu dan dimana-mana dapat terulang. Dikutip dari King Faisal Sulaiman, Teori Peraturan Perundang-undangan dan Aspek Pengujiannya (Yogyakarta: Thafa Media, 2016), 65.

${ }^{23}$ Maria Farida Indrati, Ilmu Perundangundangan Jenis, Fungsi, dan Muatan (Yogyakarta: Kanisius, 2007), 55-56. legi inferior sangat penting untuk kepastian hukum. ${ }^{24}$

\section{Substansi Pengaturan Gadai Swasta dengan Sistem Online}

Substansi atau hal apa saja yang penting untuk diatur yakni pertama, berhubungan erat dengan saat terjadinya hak gadai bahwa untuk terjadinya hak gadai terdapat 2 (dua) macam tahapan, tahapan perjanjian pinjam uang dengan janji sanggup memberikan benda bergerak sebagai jaminan, dan tahap penyarahan benda gadai dalam kekuasaan penerima gadai. Sehingga hak gadai terjadi ketika 2 (dua) tahapan tersebut terpenuhi.

Objek benda gadai adalah berupa benda bergerak dan benda itu harus dilepaskan dari kekuasaan debitor ${ }^{25}$ dan konsep penyerahan itu harus secara yuridis dan nyata. ${ }^{26}$

Substansi pengaturan penyerahan gadai online adalah yang pertama, kurir atau jasa angkut dari perusahan gadai tersebut datang bersama-sama dengan penaksir yang bersertifikat dan telah tersertfikasi (yang sebelumnya nasabah sudah mengakses pada situs web gadai online tersebut) dan sekaligus membawa alat taksir sesuai dgn kebutuhan barang yang dijaminkan. Kedua, debitor menyerahkan barang bergerak yang dijadikan jaminan tersebut ke mitra yg bekerjasama dengan perusahaan gadai online tersebut.

Kedua, terkait penaksir disebutkan di dalam ketentuan pasal 19 ayat (1) POJK Usaha Pergadaian bahwasanya “... wajib memiliki paling sedikit 1 org penaksir untuk

\footnotetext{
${ }^{24}$ Muchar Kusuma Atmadja, Konsep-konsep Hukum dalam Pembangunan (Bandung: Alumni, 2002), 63.

${ }^{25}$ Bahwa penyerahan kekuasaan atas barang objek gadai kepada kreditor (atau kepada orang lain yang disetujui) menurut hukum merupakan syarat hukum memaksa (dwingend recht, mandatory law), jadi tidak dapat dikesampingkan oleh para pihak. Dikutip dari Munir Fuady, Konsep Hukum Perdata (Jakarta: PT. RajaGrafindo Persada, 2014), 132.

${ }^{26}$ Lihat ketentuan Pasal 612 KUHPerdata, bahwasanya penyerahan benda bergerak tersebut harus secara yuridis dan nyata.
} 
melakukan penaksiran atas barang jaminan pada setiap unit pelayanan". ${ }^{27}$ Disebutkan juga bahwasanya penaksir tersebut juga harus lulus sertfikasi penaksiran barang jaminan. $^{28}$

Menjadi berbeda karena model penaksiran hanya berdasarkan pengakuan yang dilakukan debitor di laman situs web atau debitor langsung mengisi kolom yang telah tersedia di laman situs web tersebut. Sehingga secara otomatis penaksiran hanya berdasarkan pengaturan baku yang diberikan oleh perusahaan gadai swasta online tersebut.

Dalam POJK Usaha Pergadaian disebutkan bahwasanya OJK mempunyai wewenang dalam hal pengawasan ${ }^{29}$ dan pemeriksaan $^{30}$ terhadap perusahaan pergadaian, diharapakan OJK dapat mengawasi gadai online dengan cara OJK perlu membentuk suatu lembaga pengawas dan pemeriksa khusus online sebab menjadi penting untuk diperhatikan mengenai sistem online nya ini. Agar jalannya kegiatan usaha-usaha gadai online tetap sesuai koridor.

Menurut penulis konsep substansi pengaturan penaksir yakni dapat berupa, di laman situs web gadai online harus mencantumkan foto penakasir, identitas penaksir (cv) penaksir; inovasi setiap nasabah yg akan menggadai menggunakan layanan video chat (agar dapat terjadi interaksi penaksir dan nasabah). ${ }^{31}$

\footnotetext{
${ }^{27}$ Lihat ketentuan Pasal 19 Ayat (1) POJK Usaha Pergadaian.

${ }^{28}$ Lihat ketentuan Pasal 19 Ayat (3) POJK Usaha Pergadaian.

${ }^{29}$ Lihat ketentuan Pasal 41 ayat (1) POJK Usaha Pergadaian, yang berbunyi “...pengawasan perusahaan pergadaian dilakukan oleh OJK." Pergadaian.

${ }^{30}$ Lihat Pasal 42 ayat (2) POJK Usaha

${ }^{31} \mathrm{Hal}$ tersebut juga berkesesuaian dengan Pasal 1320 KUHPerdata mengenai syarat sah perjanjian. Ketika debitor dan penaksir melakukan video chat (berinteraksi) tersebut dapat diketahui bahwa debitor sepakat mengadakan pinjaman dengan jaminan barang bergerak gadai, debitor dan penaksir tersebut cakap melakukan perbuatan hukum dalam
}

Ketiga, terkait lingkup wilayah usaha sangat berhubungan erat dengan modal disetor suatu perusahaan gadai, hal ini tercantum di dalam ketentuan pasal 4 ayat (1) POJK Usaha Pergadaian yakni “... modal disetor perusahaan pergadaian berdasarkan lingkup wilayah usaha yaitu kabupaten/kota atau provinsi. ${ }^{32}$ Maka dari itu gadai swasta memiliki cakupan wilayah kerja sebatas kota/kabupaten atau provinsi. Adapun alasan lain kenapa hanya diberikan izin di satu kabupaten, kota atau provinsi agar bisnis gadai swasta ini tidak dimonopoli oleh konglomerasi. OJK mendorong pengusaha-pengusaha lokal agar tumbuh menjadi penguasa bisnis pegadaian di tingkat kabupaten atau kota dan di tingkat provinsi. ${ }^{33}$

Namun kemudian ini menjadi masalah, karena gadai dengan sistem online lingkup wilayah usahanya tanpa dibatasi oleh batas wilayah (borderless). Hal ini dikarenakan layanan gadai swasta dengan sistem online dilakukan di dunia maya atau melalui media internet bahkan dimungkinkan gadai swasta dengan sistem online beroperasi hanya melalui online office atau media laman internet saja. Keberadaan pegadaian dengan sistem online pada praxisnya tidak terikat ruang wilayah administratif karena sifatnya yang global melintasi batas wilayah administratif manapun. Sehingga konsepnya adalah ketika suatu perusahaan gadai yang akan membuka layanan kegiatan dengan sistem online akan melalukan proses seperti menyetorkan modal disetor sebesar modal lingkup wilayah usaha kabupaten/kota,

\footnotetext{
hal ini gadai, kemudian suatu hal tertentu yakni beruapa barang yang dijadikan sudah di tentukan jenisnya, dan yang terakhir suatu sebab yang halal, dalam membuat perjanjian tersebut tidak boleh bertentangan dengan kesusilaan, ketertiban umum dan undang-undang.

${ }^{32}$ Lihat ketentuan Pasal 4 Ayat (1) POJK Usaha Pergadaian.

${ }^{33}$ http://republika.co.id/berita/koran/financia 1/16/10/05/oekmki10-ojk-atur-pegadaian. Diakses pada tanggal 15 April 2018.
} 
provinsi suatu perusahaaan gadai. Maka dari pada itu perusahaan gadai dengan sistem online, perusahaan gadai itu diwajibkan memilki outlet. Sehingga, modal disetornya sesuai dengan suatu kabupaten/kota, provinsi tetapi perusahaan gadai tersebut membuka layanan kegiatan perusahaan gadai melalui online, dan dimungkinkan menjalin kerjasama atau mitra dengan perusaahan lain. Agar kegiatan yang dilakukan oleh OJK untuk mendorong pengusaha-pengusaha lokal tumbuh menjadi penguasa bisnis pegadaian dan untuk melindungi (proteksi) kepada pengusaha lokal kecil dapat tercapai, seyogyanya konsep tersebut dapat memberikan kepastian hukum dalam hal ruang lingkup usaha gadai.

Keempat, terkait dengan kemitraan, ditemukan ada salah satu perusahaan gadai swasta online yang menjalankan kegiatan usahanya dengan menjalin kerjasama atau mitra. Sebagai contoh PT. Gadai Pinjam Indonesia perusahaan yang berbasis financial technology (fintech) dengan situs web Pinjam.co.id bermitra dengan PT. Pos Indonesia (Persero). Selanjutnya Pinjam.co.id menjalin mitra dengan Columbia Cash \& Kredit yang bergerak di bisnis penjualan dan pembiayaan untuk barang elektronik, furniture dan sepada motor.

Alas hak perjanjian kerjasama kemitraan usaha antara perusahaan gadai swasta online dengan perusahaan lain keberadaannya didasarkan atas asas kebebasan berkontrak. ${ }^{34}$ Lebih lanjut untuk dapat terselenggaranya kerjasama kemitraan dalam gadai swasta online, syarat umum bagi sahnya suatu perjanjian dibuat dengan memenuhi syarat-syarat sah perjanjian ${ }^{35}$ dan perjanjian itu dibuat tidak dengan maksud bertentangan dengan hukum atau dengan

\footnotetext{
${ }^{34}$ Lihat ketentuan Pasal 1338 ayat (1) KUHPerdata yang berbunyi “... semua perjanjian yang dibuat secara sah berlaku sebagai undangundang bagi mereka yang membuatnya".

${ }^{35}$ Lihat ketentuan Pasal 1320 KUHPerdata.
}

tujuan-tujuan yang merugikan kepentingan umum (individu, masyarakat dan negara), dan atau tidak sesuai dengan perasaan keadilan atau kesusilaan masyarakat. ${ }^{36}$

Namun pengaturan mengenai kemitraan tidak diatur di dalam POJK Usaha Pergadaian, sebab menjadi penting untuk diatur terkait masalah bagaimana pertanggungjawaban mitra tersebut apabila barang gadai yang yang telah diserahkan oleh debitor musnah atau hilang pada mitra tersebut. Sehingga, harus mengetahui terlebih dahulu hubungan hukum yang terjalin diantara gadai online tersebut apakah mitra sebagai pihak ke-3 (tiga) yang memegang barang jaminan tersebut, ${ }^{37}$ atau apakah mitra tersebut terjalin atas hubungan hukum penitipan barang. ${ }^{38}$ Maka harus lihat terlebih dahulu hubungan hukum kerjasama apa yang terjalain antara gadai online dengan mitra.

Maka dari itu untuk perusahaan gadai online, yang tidak memiliki outlet secara offline, perusahaan gadai online tersebut wajib menjalin kerjasama/mitra dengan perusahaan lain. Konsep substansi pengaturannya; setelah nasabah atau debitor melakukan penaksiran secara online, kemudian debitor datang ke mitra resmi perusahaan gadai online tersebut untuk penyerahan barang kemudian pencairan danya langsung ditransfer ke rekening nasabah tersebut.

Kelima, terkait dengan izin untuk mendirikan suatu perusahaan gadai swasta dengan sistem online, karena disebutkan di

\footnotetext{
${ }^{36}$ Amirizal, Hukum Bisnis Deregulasi dan Joint Venture di Indonesia Teori dan Praktik (Jakarta: Djambatan, 1996), 36.

${ }^{37}$ Di dalam ketentuan Pasal 1152 Ayat (1) KUHPerdata bahwasanya “...diletakkan dengan membawa barang gadainya dibawah kekuasaan si berpiutang di bawah kekuasaan si berpiutang atau seorang pihak ketiga tentang siapa yang mana harus disetujui oleh para belah pihak".

${ }^{38}$ Lihat ketentuan Pasal 1694 KUHPerdata yang berbunyi “... penitipan adalah terjadi, apabila seseorang menerima sesuatu barang dari seseorang lain, dengan syarat bahwa ia akan menyimpannya dan mengembalikan dalam wujud asalnya”.
} 
dalam ketentuan pasal 9 ayat (1) POJK Usaha Pergadaian bahwasanya “... perusahaan pergadaian melakukan kegiatan usaha setelah memperoleh izin dari OJK", 39

Usaha Pergadaian dalam OJK diperbolehkan adanya layanan kegiatan usaha melalui media elektronik namun di sisi lain dalam tahap permohonan izin tidak diatur atau tidak memperhitungkan bagaimana layanan kegiatan melalui media elektronik (online) seperti apa. Menjadi sangat penting untuk diatur sebab disebutkan di POJK Pergadaian dalam tahap permohonan izin bukti kepemilikan gedung atau sertifikat haknya, ${ }^{40}$ kemudian bagaimana apabila perusahaan gadai tersebut membuka layanan kegiatannya dengan sistem online.

Sesuai dengan tujuan hukum yang mencipatakan kepastian hukum menunjuk kepada pemberlakukan hukum yang jelas, konsisten dan konsekuen yang pelaksanaanya tidak bisa dipengaruhi keadaan-keadaan yang bersifat subjektif seharusnya permohonan untuk izin gadai online ditambah atau ditambahkan aspek onlinenya, seperti ketika mengajukan bukti kesiapan operasional di cantumkan situs web nya, kira-kira situs web-nya akan seperti apa bentuknya, isi situs web, kemudian contoh surat bukti surat gadai dalam bentuk elektronik, sertipikat penaksir, dan rencana kerja untuk 1 (satu) tahun pertama seperti gambaran mengenai kegiatan usaha online yang akan dilakukan, target dan langkah-langkah yang dilakukan untuk mewujudkan target yang dimaksud misalnya melakukan kemitraan dengan perusahaan-perusahaan lain. Sehingga konsep untuk gadai swasta dengan sistem online terikait izin, sesuai dengan tujuan hukum yang mencipatakan kepastian hukum menunjuk kepada pemberlakukan hukum yang jelas, konsisten dalam hal mengajukan

\footnotetext{
${ }^{39}$ Lihat ketentuan Pasal 9 Ayat (1) POJK Usaha Pergadaian.

${ }^{40}$ Lihat ketentuan Pasal 9 Ayat (2) Huruf G POJK Usaha Pergadaian.
}

permohonan izin usaha kepada OJK harus ada keterangan bahwasanya akan menjalankan kegiatan usaha online. Konsep selanjutnya apabila dalam hal permohonan disetujui OJK, OJK menetapkan keputusan pemberian izin usaha sebagai usaha gadai swasta dengan sistem online, dengan harapan OJK dapat mengetahui daftar perusahan gadai yang menjalankan usaha dengan sistem online dan dapat mengawasi.

Keenam, terkait dengan barang yang dapat digadaikan. Barang yang dapat diajadikan jaminan gadai berupa barang bergerak dan mempunyai nilai ekonomis. Namun, penulis menemukan dalam salah satu situs web gadai online barang yang dapat digadaikan berupa: 1) $\mathrm{BPKB}^{41}$ Bus; 2) BPKB Mobil; 3) BPKB Motor; 4) BPKB Truk; 5) Sertipikat Bangunan; 6) Sertifikat Tanah. Hal ini perlu menjadi perhatian karena tanah termasuk benda tidak bergerak dan sudah ada lembaga jaminan tersendiri, yaitu lembaga jaminan hak tanggungan dan sudah ada aturannya tersendiri di dalam Undang-Undang Nomor 4 Tahun 1996 tentang Hak Tanggungan atas Tanah Beserta Benda-Benda yang Berkaitan dengan Tanah. Kemudian mobil, motor, bus, truk memang termasuk benda bergerak, tetapi yang perlu menjadi perhatian ketika kedudukan sertifikat atau BPKB yang dijadikan jaminan gadai tersebut. Pada prinsipnya gadai tersebut, terjadi penyerahan nyata (feitelijke levering) penyerahan benda bergerak secara nyata dari suatu benda, sehingga benda tersebut di alihkan ke dalam kekuasaan yang nyata dari pihak lawan. ${ }^{42}$

Hal ini berkesesuaian dengan prinsip dasar gadai yang tercantum di dalam

\footnotetext{
${ }^{41}$ Apabila dilihat dari pengertian BPKB adalah buku yang dikeluarkan atau diterbitkan oleh satuan lalu lintas Polri sebagai bukti kepemilikan kendaraan bermotor, dan BPKB berfunsgi sebagai surat bukti kepemilikan kendaraan bermotor. https://www.polri.go.id/pdf/Layanan\%20BPKB\%20 \&\%20STNK.pdf. Diakses pada tanggal 12 April 2018.

${ }^{42}$ Salim, Pengantar Hukum Perdata Tertulis (BW) (Jakarta: Sinar Grafika, 2001), 108.
} 
KUHPerdata yang mana barang bergerak yang dijadikan jaminan tersebut harus dikeluarkan dari kekuasan debitor dan di alihkan kepada kreditor (inbezitstelling) tujuannya untuk menahan barang yang dijadikan jaminan sampai utang debitor itu lunas, jadi bukan BPKB-nya yang dijadikan jaminan karena hal itu akan berhubungan erat dengan eksekusi barang jaminan gadai tersebut. Sudah pasti yang di eksekusi barang bergerak bergeraknya seperti mobil, motor bukan bukti kepemilikan kendaraan bermotor tersebut. Sehinga apabila yang dijadikan jaminan BPKB barang-barang tersebut tidak termasuk dalam prinsip gadai yang sesuai dengan ketentuan di dalam pasal 1150-pasal 1160.

Maka dari itu, diperlukan suatu aturan dalam hal ini OJK yang berwenang mengatur bahwasanya perusahaan gadai swasta online tersebut dalam menjalankan kegiatan usahanya tidak boleh bertentangan dengan prinsip dasar gadai yang tercantum di dalam KUHPerdata itu sendiri. Sehingga apabila berpedoman dengan prinsip dasar gadai itu sendiri, penulis mengkonsepkan bahwasanya sebagai langkah preventifnya dengan cara OJK membuat aturan mengenai barang apa saja yang dapat digadaikan di perusahaan gadai swasta online tersebut. Selanjutnya, sebagai langkah represifnya untuk meneritibkan perusahaan gadai swasta dengan sistem online dengan cara OJK memberikan sanksi kepada perusahaan gadai swasta online berupa peringatan tertulis, pembekuan izin usaha, dan pecabutan izin usaha.

\section{KESIMPULAN}

Berdasarkan hasil penelitian yang dilakukan, dapat diambil 2 (dua) kesimpulan, yaitu pertama, urgensi pengaturan perusahaan gadai swasta dengan sistem online adalah terdapat disharmonisasi pengaturan gadai milik negara, gadai swasta offline dan gadai swasta dengan sistem online. Selain itu tidak adanya pengaturan terkait penyerahan barang, terkait penaksir, terkait dengan lingkup wilayah usaha, terkait kemitraan, terkait izin dan terkait dengan barang apa yang dapat digadaikan menyebabkan kekosongan hukum gadai swasta dengan sistem online.

Kedua, pengaturan yang dibutuhkan perusahaan gadai swasta dengan sistem online adalah harmonisasi pengaturan sesuai hierarki tata urutan peraturan perundangundangan, yakni undang-undang hingga peraturan di bawahnya. Secara substantif terkait penyerahan, terkait penaksir, terkait dengan lingkup wilayah usaha, terkait kemitraan, terkait izin dan terkait dengan barang apa yang dapat digadaikan dalam gadai swasta dengan sistem online yang sesuai dengan teori-teori pada hukum gadai yang ada untuk mengakhiri kondisi kekosongan hukum pada gadai swasta dengan sitem online.

\section{DAFTAR PUSTAKA}

Amirizal. Hukum Bisnis Deregulasi dan Joint Venture di Indonesia Teori dan Praktik. Jakarta: Djambatan, 1996.

Atmadja, Muchtar Kusuma. Konsep-konsep Hukum dalam Pembangunan. Bandung: Alumni, 2002.

Budiono, Abdul Rachmad. Pengantar Ilmu Hukum. Malang: Bayumedia Publishing, 2005.

Fuady, Munif. Konsep Hukum Perdata. Jakarta: PT. RajaGrafindo Persada, 2014.

Hermansyah. Hukum Perbankan Nasional Indonesia. Jakarta: Kencana Prenadamedia Group, 2005.

Indrati, Maria Farida. Ilmu Perundangundangan Jenis, Fungsi, dan Muatan, Yogyakarta: Kanisius, 2007.

Inklusi Keuangan Program Pemerintah, dikutip dari, http://finansial.bisnis.com/read/20180 213/9/738201/jokowi-beberkanpenghambat-perluasan-inklusikeuangan-indonesia.

Isrok. Masalah Hukum Jangan Dianggap Sepele Menyoal The Devils Is In The Detail Sebagai Konsep Teori. Malang: Fakultas Hukum Universitas 
Brawijaya, 2017.

Kitab Undang-Undang Hukum Perdata (KUHPerdata).

Layanan Buku Kepemilikan Kendaraan Bermotor (BPKB) dan Surat Tanda Nomor Kendaraan, dikutip dari, https://www.polri.go.id/pdf/Layanan\% 20BPKB\%20\&\%20STNK.pdf.

Mertokusumo, Sudikno. Penemuan Hukum Sebuah Pengantar. Yogyakarta: Liberty, 2006.

Peraturan Otoritas Jasa Keuangan Nomor 31/POJK.05/2016 tentang Usaha Pergadaian.

Peraturan Otoritas Jasa Keuangan Nomor Nomor 77/Pojk.01/2016 Tentang Layanan Pinjam Meminjam Berbasis Teknologi Informasi (Fintech).

Peraturan Pemerintah Republik Indonesia Nomor 103 Tahun 2000 tentang Perusahaan Umum (Perum) Pegadaian.

Peraturan Pemerintah Republik Indonesia Nomor 51 Tahun 2011 Tentang Perubahan Bentuk Badan Hukum Perusahaan Umum (Perum) Pegadaian Menjadi Perusahaan Perseroan (Persero).

Safa'at, Muhammad Ali. Antonasi Pemikiran Hukum. Malang: UB Press, 2014.

Salim. Perkembangan Hukum Jaminan di Indonesia. Jakarta: Sinar Grafika, 2001.

Pengantar Hukum Perdata Tertulis $(B W)$. Jakarta: PT. RajaGrafindo Persada, 2016.

Soekanto, Soerjono dan Punardi Purbacaraka, Aneka Cara Pembedaan Hukum. Bandung: PT. Citra Aditya Bakti, 1994.

Subekti. KUHPerdata. Jakarta: Pradyana Paramita, 2001.

Sulaiman, King Faisal. Toeri Peraturan Perundang-undangan dan Aspek Pengujiannya. Yogyakarta: Thafa Media 2016.

Undang-Undang Nomor 12 Tahun 2011 Tentang Pembentukan Peraturan
Perundang-Undangan.

Undang-Undang Nomor 21 Tahun 2011 Tentang Otoritas Jasa Keuangan.

Undang-Undang Nomor 3 Tahun 2004 Tentang Bank Indonesia.

Untung mana pinjam dari bank, pegadaian, atau rentenir online? https://www.merdeka.com/uang/untun g-mana-pinjam-dari-bank-pegadaianatau-rentenir-online.html. 